\title{
Reference curves of birth weight, length, and head circumference for gestational ages in Yogyakarta, Indonesia
}

\author{
Ekawaty L. Haksari ${ }^{*}$, Harrie N. Lafeber ${ }^{2}$, Mohammad Hakimi $^{3}$, Endy P. Pawirohartono ${ }^{1}$ and Lennarth Nyström ${ }^{4}$
}

\begin{abstract}
Background: The birth weight reference curve to estimate the newborns at risk in need of assessment and monitoring has been established. The previous reference curves from Indonesia, approximately 8 years ago, were based on the data collected from teaching hospitals only with limited gestational ages. The aims of the study were to update the reference curves for birth weight, supine length and head circumference for Indonesia, and to compare birth weight curves of boys and girls, first child and later children, and the ones in the previous studies.

Methods: Data were extracted from the Maternal-Perinatal database between 1998-2007. Only live singletons with recorded gestational ages of 26 to 42 weeks and the exact time of admission to the neonatal facilities delivered or referred within $24 \mathrm{~h}$ of age to Sardjito Hospital, five district hospitals and five health centers in Yogyakarta Special Territory were included. Newborns with severely ill conditions, congenital anomaly and chromosomal abnormality were excluded. Smoothening of the curves was accomplished using a third-order polynomial equation.
\end{abstract}

Results: Our study included 54,599 singleton live births. Growth curves were constructed for boys (53.3\%) and girls (46.7\%) for birth weight, supine length, and head circumference. At term, mean birth weight for each gestational age of boys was significantly higher than that of girls. While mean birth weight for each gestational age of firstborn-children, on the other hand was significantly lower than that of later-born-children. The mean birth weight was lower than that of Lubchenco's study. Compared with the previous Indonesian study by Alisyahbana, no differences were observed for the aterm infants, but lower mean birth weight was observed in preterm infants.

Conclusions: Updated neonatal reference curves for birth weight, supine length and head circumference are important to classify high risk newborns in specific area and to identify newborns requiring attention.

Keywords: Reference curve, Birth weight, Supine length, Head circumference, Sex, First-later-born children, Preterm term

\section{Background}

Size at birth reflects fetal growth and health as well as provides important information on the newborns infant. Many studies have been carried out to construct a theoretical birth weight curve for gestational age $[1,2]$. The birth size curve was used as a reference to facilitate prediction of growth, estimate the risk for small gestational age (SGA), and to identify newborns at risk that require assessment and monitoring during the neonatal period [3-7].

\footnotetext{
* Correspondence: ekahaksari@yahoo.com

'Department of Child Health, Faculty of Medicine, Gadjah Mada University, Sardjito General Hospital, Jl. Kesehatan No. 1, Yogyakarta 55284, Indonesia Full list of author information is available at the end of the article
}

The prevalence of high risk newborns depends on the birth curve used [8]. Therefore, a perinatal growth chart that is versatile enough to serve as an international reference and at the same time simple to understand, to reproduce, and to use is needed [9]. However, data suggests that reference curves from other populations may not be representative, thus it is important to develop region-and population-specific reference curves [10-16]. Consequently, gender-specific population-based reference curves are expected to improve the clinical assessment of growth in newborns and evaluation of interventions [17]. In addition, update of the reference curves every $10-15$ year is necessary to adjust the curves for changes in the population over time [18-23]. Hence, 
fetal growth may be assessed in longitudinal studies, clinically or through ultrasound scans. Nevertheless, birth weight and estimated intrauterine fetal weight are not always comparable especially at earlier periods of gestation. Thus, the birth weight data should not be used to calculate intrauterine growth rate [24].

Today clinicians in most developing countries are using the Lubchenco's reference curve for newborns $[1,25]$. However, most neonatology centers in developed countries in Europe use the Niklasson's curve [19]. Indonesian clinicians, on the other hand, have emphasized the importance of establishing national reference curves. Alisyahbana's study developed reference curves for 5844 newborns with 34-44 weeks based on data from 14 teaching hospitals in Indonesia from July 1,1990 to June 30,1991 [26]. The result showed that the mean birth weight of Lubchenco's newborns was significantly different than that from Alisyahbana's, therefore the Lubchenco's curve cannot be used as reference curve for Indonesian newborns.

In 1992 the Maternal-Perinatal (MP) team was established in Yogyakarta with the aim of conducting MP audits and creating an MP database in the district hospitals including data collection on birth weight, supine length and head circumference of newborns. The aims of this study were to update the reference curves for birth weight, supine length and head circumference for Yogyakarta, Indonesia and to compare birth weight curves of boys and girls, first child and later children, and the ones in the previous studies.

\section{Methods}

\section{Study population and study period}

The study was conducted in Yogyakarta Special Territory (YST) whose population is made up of various ethnics in Indonesia. Nevertheless it has not represented the population of Indonesia as a whole. YST consist of five districts. Each district is served by a district hospital and a couple of health centers, of which only one was equipped for deliveries, and the referral hospital Sardjito. During the study period January 1, 1998 to December 31, 2007 all deliveries at Sardjito Hospital, the five district hospitals, and the five health centers equipped for deliveries were recorded. Approximately, $80 \%$ of the newborns in YST were delivered by trained health personnel, $65 \%$ of whom were delivered in Sardjito Hospital, five district hospitals and five health centers; the remaining 35\% was delivered in private hospitals, maternity clinics, midwife clinics or at home by midwives [27].

Our study population consisted of all newborns delivered at Sardjito Hospital, five district hospitals, five health centers and those referred from other health facilities within $24 \mathrm{~h}$ of birth.
Lubchenco [1, 25], Niklasson [19], and Alisyahbana [26] presented birth weight using gestational age curves for singleton, live born, and healthy newborns. The study population of Lubchenco was collected from Colorado General Hospital, Niklassons from the Swedish Medical Birth Register and it covers the whole Sweden, and Alisyahbana from 14 teaching hospitals in Indonesia (Table 1).

\section{Maternal-Perinatal database}

The study was conducted by MP team based on MP database. The MP database in the district hospitals is part of MP audit, which is a district-based audit of maternal and perinatal mortality. The MP audit was introduced in Indonesia as a tool for continuous surveillance of the maternal-perinatal mortality and quality assurance of the obstetric and perinatal services into the domain of district health system $[28,29]$.

The MP database was run in every district hospital by filling in the MP form daily. The data were validated monthly by the local team before they were sent to the MP center at the beginning of the next month and were computerized by a trained secretary. The data generation process from data collection, field editing, data form submission to the data center, and to data entry were continuously monitored to identify errors and logical inconsistencies.

In Indonesia, primary health care services are conducted in health centers. The district hospitals are secondary health facilities that provide referral services in that area. Tertiary health facilities are made available at teaching hospitals, which are usually found in the capital of a province. However, for provinces without a teaching hospital, the services are provided by the provincial hospital, a government hospital in the capital of the province.

The forms from the five district hospitals in YST were submitted to the MP center at Sardjito Hospital until 2001, meanwhile the MP team in the center checked and entered the data. However, from 2002 onwards all facilities were checked and they entered the data by themselves. Therefore the 1998-2001 data were available in the MP center while the 2002-2007 data were available in the health facilities. Unfortunately, an earthquake struck the area in May 2006 and damaged the soft copy in computers, thus causing most of the data to be re-entered from the MP forms.

The MP database contained information from the mother's delivery to the neonatal period for each individual in the maternity and newborns facilities in YST. The newborns were followed up until they were discharged from the facilities. Trained health personnel filled in the MP forms. They contained information on identity, 
Table 1 A comparison of the present study with the previous studies

\begin{tabular}{|c|c|c|c|c|c|c|c|c|c|c|c|}
\hline \multirow[t]{2}{*}{ Reference } & \multirow[t]{2}{*}{ Study area } & \multirow{2}{*}{$\begin{array}{l}\text { Study } \\
\text { population }\end{array}$} & \multirow{2}{*}{$\begin{array}{l}\text { Study } \\
\text { period }\end{array}$} & \multirow{2}{*}{$\begin{array}{l}\text { Sample } \\
\text { size }\end{array}$} & \multicolumn{4}{|l|}{ Subjects } & \multicolumn{3}{|l|}{ Analysis } \\
\hline & & & & & $\begin{array}{l}\text { All/live } \\
\text { births }\end{array}$ & $\begin{array}{l}\text { All/ } \\
\text { Singleton }\end{array}$ & $\begin{array}{l}\text { GA } \\
\text { (weeks) } \\
\text { Method }\end{array}$ & $\begin{array}{l}\text { Congenital } \\
\text { anomalies } \\
\text { included }\end{array}$ & Gender & $\begin{array}{l}\text { Mean } \\
\pm \text { SD } \\
\text { by GA }\end{array}$ & $\begin{array}{l}\text { Percentiles } \\
\text { by GA }\end{array}$ \\
\hline $\begin{array}{l}\text { Lubchenco } \\
{[1,25]}\end{array}$ & $\begin{array}{l}\text { US (Denver, } \\
\text { Colorado) }\end{array}$ & $\begin{array}{l}\text { Colorado } \\
\text { General Hospital }\end{array}$ & 1948-61 & 7827 & Live & All & $\begin{array}{l}\text { 24-42 } \\
\text { LMP }\end{array}$ & No & Yes & No & Yes \\
\hline $\begin{array}{l}\text { Niklasson } \\
\text { [19] }\end{array}$ & Sweden & $\begin{array}{l}\text { Medical birth } \\
\text { registration }\end{array}$ & $1977-81$ & 475,588 & Live & Singleton & $\begin{array}{l}28-42 \\
\text { LMP \& } \\
\text { USG }\end{array}$ & No & Yes & Yes & No \\
\hline Kramer [18] & $\begin{array}{l}\text { Canada, } \\
\text { except } \\
\text { Toronto }\end{array}$ & Provinces & 1994-96 & 676,605 & All & Singleton & $\begin{array}{l}22-43 \\
\text { USG }\end{array}$ & Yes & Yes & Yes & Yes \\
\hline $\begin{array}{l}\text { Alisyahbana } \\
\text { [26] }\end{array}$ & Indonesia & $\begin{array}{l}14 \text { teaching } \\
\text { hospitals }\end{array}$ & 1990-91 & 5844 & Live & Singleton & 34-44 LMP & No & Yes & No & Yes \\
\hline Ulrich M [12] & $\begin{array}{l}\text { Denmark } \\
\text { (Odense) }\end{array}$ & Residents & 1978 & 906 & Live & Singleton & $\begin{array}{l}25-43 \\
\text { USG \& } \\
\text { Dubowitz }\end{array}$ & No & Yes & Yes & No \\
\hline Matthai [24] & $\begin{array}{l}\text { India } \\
\text { (Velore) }\end{array}$ & $\begin{array}{l}\text { Christian hospital } \\
(n=13,217)\end{array}$ & 1991-94 & 11,641 & Live & Singleton & $\begin{array}{l}37-41 \\
\text { Clinical } \\
\text { \&USG }\end{array}$ & $\begin{array}{l}\text { No } \\
\text { (normal) }\end{array}$ & Yes & No & $\begin{array}{l}\text { Yes (only } \\
10,50,90)\end{array}$ \\
\hline Fok [20] & Hongkong & $\begin{array}{l}\text { Chinese origin } \\
(n=104,258)\end{array}$ & 1998-2001 & 10,339 & Live & Singleton & $\begin{array}{l}24-43 \\
\text { (USG \& } \\
\text { Ballard) }\end{array}$ & No & Yes & Yes & Yes \\
\hline Visser [21] & $\begin{array}{l}\text { The } \\
\text { Netherland }\end{array}$ & $\begin{array}{l}\text { The Netherlands } \\
\text { Perinatal Registry } \\
(n=183,000)\end{array}$ & 2001 & 176,000 & $\begin{array}{l}\text { Live \& } \\
\text { intrapartum } \\
\text { death }\end{array}$ & Singleton & $\begin{array}{l}25 \\
\text { onwards } \\
\text { LMP \&USG }\end{array}$ & Yes & Yes & Yes & Yes \\
\hline $\begin{array}{l}\text { Present } \\
\text { study }\end{array}$ & $\begin{array}{l}\text { Indonesia } \\
\text { (Yogyakarta) }\end{array}$ & $\begin{array}{l}\text { Sardjito, } 5 \text { district } \\
\text { hospitals, \& } 5 \\
\text { health centers } \\
(n=59,609)\end{array}$ & 1998-2007 & 54,599 & Live & Singleton & $\begin{array}{l}\text { 26-42 } \\
\text { (Dubowitz) }\end{array}$ & No & Yes & Yes & Yes \\
\hline
\end{tabular}

characteristics of the mothers, their pregnancy and delivery, and the newborns.

\section{Inclusion and exclusion criteria}

Only live singletons with recorded gestational ages between 26 to 42 weeks and the exact time of admission to the neonatal facility were included in the study; meanwhile those with severely ill conditions (severe asphyxia, severe cardio-respiratory distress, etc.), major congenital anomaly, and those admitted $>24$ h of age were excluded.

\section{Assessment of gestational age}

In most developing countries, women especially in rural areas are unaware of the exact date of their last menstrual period (LMP). Thus, they could not calculate the expected date of delivery using the first date of the last menstrual period. Dubowitz [30] developed a clinical assessment of gestational age for newborns. A scoring system for gestational age, based on 10 neurologic and 11 external criteria. The correlation coefficient for the total score against gestation was 0.93 . The error of prediction of a single score was 1.02 weeks and of the average of two independent assessments was 0.7 weeks. The method gives consistent results within the first 5 days and is
Table 2 Basic characteristics of the study population $(n=54,599)$

\begin{tabular}{llll}
\hline Characteristic & Category & No & $\%$ \\
\hline Health facility & Sardjito hospital & 13,726 & 25.1 \\
& District hospitals & 30,574 & 56.0 \\
& Health centers & 10,299 & 18.9 \\
Gender & Boys & 29,112 & 53.3 \\
& Girls & 25,487 & 46.7 \\
Birth order & First (1 ${ }^{\text {st }}$ child) & 26,189 & 48.0 \\
& Later ( $\geq 2^{\text {nd }}$ child) & 28,410 & 52.0 \\
Admitted to neonatal & Born in the hospital/health & 45,414 & 83.2 \\
ward & centre & & \\
& Referred $<24 \mathrm{~h}$ & 9,185 & 16.8 \\
Education of mother & $\leq 5$ & 1,803 & 3.8 \\
(years) & $6-12$ & 40,196 & 82.7 \\
& $\geq 13$ & 6,576 & 13.5 \\
Age of mother (years) & $\leq 19$ & 1,770 & 3.3 \\
& $20-34$ & 43,737 & 81.0 \\
& $\geq 35$ & 8,456 & 15.7 \\
& Birth weight & 54,599 & 100 \\
Number of registered & Length & 52,261 & 95.7 \\
infants & Head circumference & 48,109 & 88.1 \\
& & &
\end{tabular}


equally reliable in the first $24 \mathrm{~h}$ of life. The scoring system is more objective and reproducible than trying to guess the gestational age on the presence or absence of individual signs. In the study, gestational age was based on clinical assessment of gestational age according to Dubowitz score and was verified by the mother's last normal menstrual period in completed weeks.

\section{Measurements}

Birth weight, supine length, and head circumference were measured immediately after delivery. All infants were weighed to the nearest $10 \mathrm{~g}$ on a balance scale (readjusted using standardized weight as part of routine care). The length was measured using a measuring board with supports for the head and feet to the nearest $\mathrm{cm}$.

Table 3 Birth weight for boys and girls by gestational age in weeks

\begin{tabular}{|c|c|c|c|c|c|c|c|c|c|c|c|c|}
\hline \multirow{2}{*}{$\begin{array}{l}\text { GA } \\
(w)\end{array}$} & \multirow{2}{*}{$\begin{array}{l}\text { No of } \\
\text { cases }\end{array}$} & \multirow{2}{*}{$\begin{array}{l}\text { Mean } \\
\text { (g) }\end{array}$} & \multirow[t]{2}{*}{ SD } & \multicolumn{9}{|c|}{ Birth weight Percentiles (g) } \\
\hline & & & & $\mathrm{P} 3$ & P5 & P10 & P25 & P50 & P75 & P90 & P95 & P97 \\
\hline \multicolumn{13}{|c|}{ Boys } \\
\hline 26 & 55 & 768.1 & 170.2 & 500 & 500 & 506 & 600 & 750 & 900 & 1000 & 1060 & 1103 \\
\hline 27 & 39 & 866.6 & 152.8 & 520 & 600 & 700 & 750 & 850 & 1000 & 1100 & 1100 & 1100 \\
\hline 28 & 50 & 968.7 & 152.9 & 600 & 600 & 800 & 900 & 1000 & 1050 & 1100 & 1168 & 1289 \\
\hline 29 & 52 & 1057 & 157.0 & 600 & 750 & 900 & 1000 & 1085 & 1130 & 1235 & 1331 & 1412 \\
\hline 30 & 70 & 1246 & 202.3 & 820 & 950 & 1000 & 1100 & 1205 & 1400 & 1547 & 1623 & 1667 \\
\hline 31 & 89 & 1409 & 282.3 & 1050 & 1063 & 1100 & 1200 & 1380 & 1525 & 1700 & 2025 & 2318 \\
\hline 32 & 223 & 1705 & 377.4 & 1172 & 1200 & 1300 & 1450 & 1650 & 1900 & 2192 & 2500 & 2600 \\
\hline 33 & 258 & 1750 & 442.7 & 1200 & 1200 & 1250 & 1400 & 1700 & 2000 & 2219 & 2562 & 2837 \\
\hline 34 & 473 & 1917 & 407.1 & 1200 & 1350 & 1400 & 1650 & 1900 & 2200 & 2400 & 2600 & 2939 \\
\hline 35 & 541 & 2035 & 378.5 & 1350 & 1400 & 1552 & 1800 & 2000 & 2250 & 2400 & 2595 & 2787 \\
\hline 36 & 868 & 2382 & 430.7 & 1650 & 1750 & 1900 & 2100 & 2350 & 2550 & 3000 & 3216 & 3400 \\
\hline 37 & 1576 & 2643 & 427.1 & 1800 & 1999 & 2150 & 2450 & 2600 & 2900 & 3200 & 3400 & 3500 \\
\hline 38 & 3799 & 2862 & 404.8 & 2100 & 2200 & 2400 & 2600 & 2800 & 3100 & 3400 & 3550 & 3700 \\
\hline 39 & 6915 & 3069 & 382.3 & 2310 & 2496 & 2600 & 2850 & 3050 & 3300 & 3500 & 3700 & 3800 \\
\hline 40 & 8755 & 3184 & 410.5 & 2414 & 2540 & 2700 & 2950 & 3180 & 3400 & 3700 & 3900 & 4000 \\
\hline 41 & 3812 & 3358 & 445.0 & 2500 & 2600 & 2800 & 3100 & 3400 & 3650 & 3900 & 4000 & 4200 \\
\hline 42 & 1537 & 3295 & 463.5 & 2500 & 2600 & 2800 & 3000 & 3250 & 3500 & 3950 & 4182 & 4300 \\
\hline \multicolumn{13}{|c|}{ Girls } \\
\hline 26 & 48 & 680.8 & 134.8 & 500 & 500 & 500 & 600 & 650 & 767 & 900 & 967 & 991 \\
\hline 27 & 41 & 844.3 & 156.2 & 600 & 609 & 700 & 770 & 800 & 900 & 1040 & 1100 & 1396 \\
\hline 28 & 59 & 945.3 & 119.2 & 600 & 700 & 800 & 900 & 1000 & 1000 & 1100 & 1100 & 1166 \\
\hline 29 & 42 & 1023 & 109.6 & 765 & 800 & 900 & 994 & 1000 & 1100 & 1141 & 1193 & 1271 \\
\hline 30 & 49 & 1151 & 230.2 & 675 & 760 & 850 & 1000 & 1100 & 1300 & 1500 & 1575 & 1665 \\
\hline 31 & 74 & 1374 & 294.1 & 825 & 975 & 1100 & 1200 & 1340 & 1500 & 1725 & 2050 & 2200 \\
\hline 32 & 171 & 1711 & 441.3 & 1100 & 1150 & 1200 & 1400 & 1600 & 1900 & 2480 & 2608 & 2700 \\
\hline 33 & 211 & 1692 & 406.2 & 1200 & 1200 & 1250 & 1400 & 1600 & 1850 & 2200 & 2520 & 2800 \\
\hline 34 & 392 & 1862 & 386.5 & 1200 & 1250 & 1400 & 1568 & 1875 & 2100 & 2300 & 2400 & 2500 \\
\hline 35 & 515 & 2046 & 386.3 & 1400 & 1500 & 1600 & 1800 & 2000 & 2250 & 2400 & 2600 & 2890 \\
\hline 36 & 812 & 2335 & 436.8 & 1500 & 1700 & 1823 & 2100 & 2300 & 2500 & 2900 & 3200 & 3300 \\
\hline 37 & 1384 & 2589 & 397.0 & 1800 & 1925 & 2145 & 2400 & 2500 & 2800 & 3100 & 3300 & 3400 \\
\hline 38 & 3318 & 2800 & 375.1 & 2100 & 2200 & 2400 & 2600 & 2800 & 3000 & 3250 & 3450 & 3600 \\
\hline 39 & 6065 & 2997 & 371.3 & 2300 & 2400 & 2600 & 2750 & 3000 & 3200 & 3450 & 3600 & 3700 \\
\hline 40 & 7607 & 3099 & 393.6 & 2400 & 2500 & 2600 & 2850 & 3100 & 3350 & 3560 & 3750 & 3900 \\
\hline 41 & 3254 & 3259 & 447.4 & 2400 & 2500 & 2700 & 3000 & 3300 & 3550 & 3800 & 4000 & 4050 \\
\hline 42 & 1445 & 3208 & 447.3 & 2400 & 2500 & 2700 & 2900 & 3200 & 3500 & 3800 & 4000 & 4200 \\
\hline
\end{tabular}


The head circumference was recorded using a measuring tape to the nearest $\mathrm{cm}$. Training and standardization in anthropometric measurements of weight, length, head circumference, and clinical assessment of gestational age by Dubowitz score were carried out in December 1997. All measurements were examined by trained nurses.

\section{Data analysis}

Data analysis was performed using SPSS version 19. Tables and graphs presented means and standard deviations (SDs) and the $3^{\text {th }}, 5^{\text {th }}, 10^{\text {th }}, 25^{\text {th }}, 50^{\text {th }}$ (median), $75^{\text {th }}, 90^{\text {th }}, 95^{\text {th }}, 97^{\text {th }}$ percentiles by gestational age relevant for clinicians in classifying newborns under their

Table 4 Length supine of boys and girls by gestational age in weeks

\begin{tabular}{|c|c|c|c|c|c|c|c|c|c|c|c|c|}
\hline \multirow{2}{*}{$\begin{array}{l}\text { GA } \\
(w)\end{array}$} & \multirow{2}{*}{$\begin{array}{l}\text { No of } \\
\text { cases }\end{array}$} & \multirow{2}{*}{$\begin{array}{l}\text { Mean } \\
(\mathrm{cm})\end{array}$} & \multirow[t]{2}{*}{ SD } & \multicolumn{9}{|c|}{ Lenght Supine Percentiles (cm) } \\
\hline & & & & $\mathrm{P3}$ & P5 & P10 & P25 & P50 & P75 & P90 & P95 & P97 \\
\hline \multicolumn{13}{|c|}{ Boys } \\
\hline 26 & 54 & 33.6 & 2.73 & 25 & 28 & 31 & 32 & 34 & 35 & 36 & 36 & 37 \\
\hline 27 & 37 & 33.9 & 3.88 & 24 & 24 & 25 & 33 & 35 & 36 & 37 & 37 & 40 \\
\hline 28 & 50 & 35.9 & 2.94 & 25 & 30 & 35 & 35 & 36 & 37 & 38 & 40 & 43 \\
\hline 29 & 50 & 37.7 & 3.18 & 29 & 35 & 35 & 36 & 38 & 39 & 40 & 43 & 45 \\
\hline 30 & 67 & 39.4 & 3.01 & 31 & 35 & 36 & 37 & 40 & 41 & 43 & 44 & 44 \\
\hline 31 & 89 & 41.3 & 2.02 & 37 & 37 & 39 & 40 & 41 & 42 & 44 & 45 & 45 \\
\hline 32 & 223 & 42.6 & 2.27 & 40 & 40 & 40 & 41 & 43 & 44 & 45 & 47 & 47 \\
\hline 33 & 258 & 42.1 & 2.89 & 36 & 37 & 38 & 41 & 42 & 44 & 46 & 47 & 48 \\
\hline 34 & 413 & 43.4 & 3.08 & 37 & 38 & 40 & 42 & 44 & 46 & 47 & 48 & 49 \\
\hline 35 & 475 & 44.0 & 3.19 & 38 & 38 & 40 & 42 & 44 & 46 & 48 & 48 & 49 \\
\hline 36 & 868 & 45.9 & 2.01 & 42 & 43 & 44 & 45 & 46 & 47 & 49 & 49 & 50 \\
\hline 37 & 1470 & 47.0 & 2.04 & 43 & 43 & 45 & 46 & 47 & 48 & 49 & 50 & 50 \\
\hline 38 & 3778 & 47.8 & 1.86 & 44 & 45 & 46 & 47 & 48 & 49 & 50 & 50 & 51 \\
\hline 39 & 6754 & 48.4 & 1.74 & 45 & 46 & 47 & 48 & 49 & 50 & 50 & 51 & 51 \\
\hline 40 & 8168 & 48.8 & 1.80 & 45 & 46 & 47 & 48 & 49 & 50 & 51 & 51 & 52 \\
\hline 41 & 3584 & 49.1 & 2.04 & 46 & 46 & 47 & 48 & 49 & 50 & 51 & 52 & 52 \\
\hline 42 & 1527 & 49.1 & 1.76 & 46 & 46 & 47 & 48 & 49 & 50 & 51 & 52 & 52 \\
\hline \multicolumn{13}{|c|}{ Girls } \\
\hline 26 & 43 & 34.1 & 2.91 & 26 & 28 & 30 & 33 & 34 & 36 & 37 & 39 & 40 \\
\hline 27 & 37 & 34.8 & 2.51 & 25 & 31 & 32 & 34 & 35 & 36 & 38 & 39 & 40 \\
\hline 28 & 59 & 35.9 & 2.07 & 33 & 33 & 34 & 35 & 36 & 37 & 40 & 40 & 42 \\
\hline 29 & 41 & 37.7 & 2.84 & 30 & 31 & 35 & 36 & 37 & 40 & 42 & 43 & 43 \\
\hline 30 & 49 & 38.8 & 2.86 & 34 & 34 & 35 & 36 & 40 & 41 & 42 & 43 & 44 \\
\hline 31 & 74 & 41.3 & 2.08 & 38 & 38 & 39 & 40 & 41 & 42 & 45 & 45 & 47 \\
\hline 32 & 171 & 42.9 & 2.16 & 40 & 40 & 41 & 41 & 43 & 44 & 46 & 47 & 47 \\
\hline 33 & 210 & 41.9 & 2.45 & 37 & 38 & 39 & 40 & 42 & 43 & 45 & 46 & 47 \\
\hline 34 & 351 & 43.1 & 3.25 & 37 & 37 & 39 & 41 & 43 & 45 & 47 & 48 & 48 \\
\hline 35 & 457 & 44.0 & 2.85 & 38 & 39 & 41 & 42 & 44 & 46 & 48 & 48 & 49 \\
\hline 36 & 812 & 45.7 & 2.20 & 41 & 42 & 43 & 45 & 46 & 47 & 48 & 49 & 50 \\
\hline 37 & 1304 & 46.7 & 1.96 & 43 & 43 & 44 & 46 & 47 & 48 & 49 & 50 & 50 \\
\hline 38 & 3299 & 47.4 & 1.78 & 44 & 45 & 45 & 46 & 47 & 49 & 50 & 50 & 51 \\
\hline 39 & 5933 & 48.0 & 1.70 & 45 & 45 & 46 & 47 & 48 & 49 & 50 & 50 & 51 \\
\hline 40 & 7074 & 48.4 & 1.79 & 45 & 46 & 46 & 47 & 48 & 49 & 50 & 51 & 51 \\
\hline 41 & 3043 & 48.7 & 2.04 & 45 & 46 & 47 & 48 & 49 & 50 & 51 & 51 & 52 \\
\hline 42 & 1439 & 48.8 & 1.70 & 45 & 46 & 47 & 48 & 49 & 50 & 51 & 52 & 52 \\
\hline
\end{tabular}


care and to researchers as well as public policy makers in comparison to geographic differences and temporal trends in birth weight for gestational ages in population. All analyses were performed separately for boys and girls. Distribution of birth weight, supine length, head circumference at the corrected gestational ages was smoothened by a third degree polynomial function. Curves were produced using Microsoft Excel 2010.

Difference in mean birth weight between boys and girls, as well as first and later-born for each gestational age was analyzed using Student's $t$-test. In the birth order of children, the term "first" refers to the $1^{\text {st }}$ child,

Table $\mathbf{5}$ Head circumference of boys' and girls' by gestational age in weeks

\begin{tabular}{|c|c|c|c|c|c|c|c|c|c|c|c|c|}
\hline \multirow{2}{*}{$\begin{array}{l}\text { GA } \\
(w)\end{array}$} & \multirow{2}{*}{$\begin{array}{l}\text { No of } \\
\text { cases }\end{array}$} & \multirow{2}{*}{$\begin{array}{l}\text { Mean } \\
(\mathrm{cm})\end{array}$} & \multirow[t]{2}{*}{ SD } & \multicolumn{9}{|c|}{ Head Circumferences Percentiles (cm) } \\
\hline & & & & $\mathrm{P3}$ & P5 & P10 & P25 & P50 & P75 & P90 & P95 & P97 \\
\hline \multicolumn{13}{|c|}{ Boys } \\
\hline 26 & 50 & 26.7 & 2.79 & 22 & 22 & 23 & 24 & 26 & 30 & 30 & 30 & 30 \\
\hline 27 & 33 & 25.9 & 2.48 & 23 & 23 & 23 & 24 & 25 & 28 & 30 & 31 & 31 \\
\hline 28 & 42 & 27.8 & 3.19 & 23 & 23 & 24 & 25 & 27 & 30 & 33 & 33 & 33 \\
\hline 29 & 35 & 29.0 & 2.83 & 24 & 25 & 26 & 27 & 28 & 32 & 33 & 33 & 33 \\
\hline 30 & 63 & 28.6 & 1.89 & 25 & 25 & 26 & 27 & 29 & 30 & 31 & 31 & 31 \\
\hline 31 & 89 & 29.2 & 1.80 & 25 & 26 & 27 & 28 & 29 & 31 & 31 & 32 & 32 \\
\hline 32 & 223 & 31.3 & 1.40 & 27 & 28 & 30 & 31 & 32 & 32 & 32 & 33 & 33 \\
\hline 33 & 256 & 30.4 & 1.86 & 26 & 27 & 28 & 30 & 31 & 32 & 32 & 33 & 34 \\
\hline 34 & 398 & 31.0 & 1.42 & 28 & 29 & 29 & 30 & 31 & 32 & 33 & 34 & 34 \\
\hline 35 & 465 & 31.2 & 1.19 & 29 & 29 & 30 & 31 & 31 & 32 & 33 & 33 & 34 \\
\hline 36 & 868 & 32.6 & 1.09 & 30 & 31 & 32 & 32 & 33 & 34 & 34 & 34 & 34 \\
\hline 37 & 669 & 32.7 & 1.18 & 30 & 30 & 31 & 32 & 33 & 34 & 34 & 34 & 35 \\
\hline 38 & 3534 & 33.3 & 0.871 & 32 & 32 & 32 & 33 & 34 & 34 & 34 & 35 & 35 \\
\hline 39 & 6296 & 33.7 & 0.778 & 32 & 32 & 33 & 34 & 34 & 34 & 35 & 35 & 35 \\
\hline 40 & 7871 & 33.9 & 0.751 & 32 & 32 & 33 & 34 & 34 & 34 & 35 & 35 & 35 \\
\hline 41 & 3463 & 34.2 & 0.763 & 32 & 33 & 34 & 34 & 34 & 35 & 35 & 36 & 36 \\
\hline 42 & 1289 & 34.1 & 0.809 & 32 & 33 & 33 & 34 & 34 & 35 & 35 & 36 & 36 \\
\hline \multicolumn{13}{|c|}{ Girls } \\
\hline 26 & 36 & 26.6 & 2.81 & 22 & 22 & 23 & 24 & 26 & 30 & 30 & 30 & 30 \\
\hline 27 & 31 & 27.0 & 2.53 & 23 & 24 & 24 & 25 & 26 & 30 & 30 & 30 & 30 \\
\hline 28 & 46 & 27.4 & 3.16 & 22 & 23 & 24 & 25 & 27 & 30 & 32 & 33 & 33 \\
\hline 29 & 31 & 29.5 & 2.36 & 25 & 26 & 26 & 28 & 30 & 31 & 33 & 33 & 33 \\
\hline 30 & 41 & 28.4 & 2.30 & 23 & 23 & 24 & 27 & 29 & 30 & 31 & 31 & 31 \\
\hline 31 & 74 & 29.3 & 1.75 & 25 & 26 & 27 & 28 & 30 & 31 & 31 & 32 & 32 \\
\hline 32 & 171 & 31.1 & 1.53 & 27 & 28 & 29 & 30 & 32 & 32 & 33 & 33 & 33 \\
\hline 33 & 207 & 30.3 & 1.75 & 27 & 27 & 28 & 29 & 30 & 32 & 32 & 33 & 33 \\
\hline 34 & 342 & 30.8 & 1.32 & 28 & 28 & 29 & 30 & 31 & 32 & 32 & 33 & 33 \\
\hline 35 & 452 & 31.2 & 1.32 & 28 & 29 & 30 & 31 & 31 & 32 & 33 & 33 & 34 \\
\hline 36 & 812 & 32.4 & 1.23 & 30 & 30 & 31 & 32 & 32 & 33 & 34 & 34 & 34 \\
\hline 37 & 608 & 32.7 & 1.26 & 30 & 30 & 31 & 32 & 33 & 34 & 34 & 34 & 35 \\
\hline 38 & 3088 & 33.2 & 0.848 & 31 & 32 & 32 & 33 & 34 & 34 & 34 & 34 & 35 \\
\hline 39 & 5544 & 33.6 & 0.774 & 32 & 32 & 33 & 34 & 34 & 34 & 35 & 35 & 35 \\
\hline 40 & 6817 & 33.8 & 0.752 & 32 & 32 & 33 & 34 & 34 & 34 & 35 & 35 & 35 \\
\hline 41 & 2964 & 34.1 & 0.778 & 32 & 33 & 33 & 34 & 34 & 35 & 35 & 35 & 36 \\
\hline 42 & 1201 & 34.0 & 0.835 & 32 & 32 & 33 & 34 & 34 & 35 & 35 & 35 & 36 \\
\hline
\end{tabular}



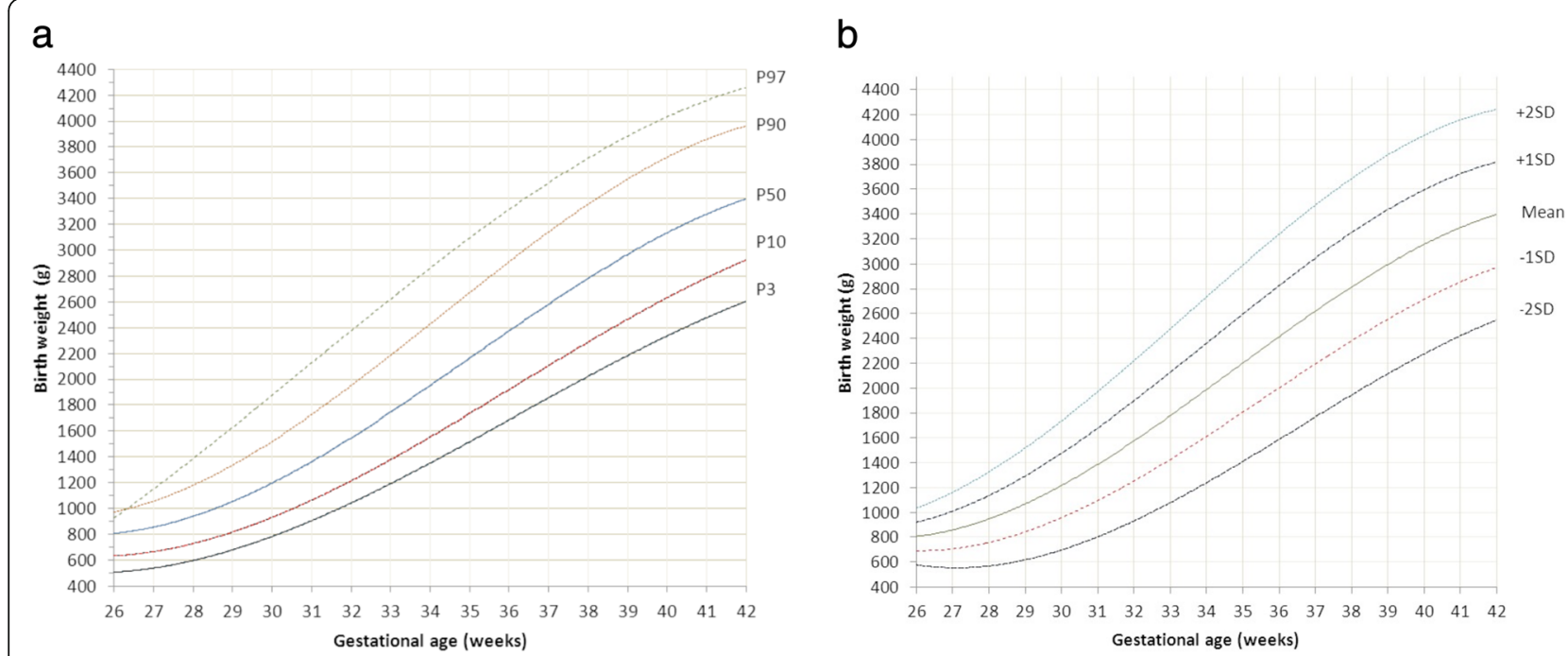

Fig. 1 a Smoothened percentiles for boys' birth weight by gestational age. b. Smoothened mean and standard deviations for boys' birth weight by gestational age

and "later" refers to second child and so on. The weightlength ratio was calculated according to Rohrer's Ponderal index (PI); $100 \mathrm{x}$ weight in grams/length [3] in centimeters and was classified by tertiles into 3 groups; low, average, or high [31]. The PI was then calculated and classified into low, average and high.

\section{Results}

From January 1998 to December 2007 there were 59,609 births. Most of the infants (83.2\%) were born in Sardjito Hospital, five district hospitals, and five health centers, whereas the others $(16.8 \%)$ were born in other hospitals, health centers, midwife clinics, at home, and were admitted to the study setting before $24 \mathrm{~h}$. In this study there were 54,599 subjects in total. Mean birth weight was 2,964 $\mathrm{g}$ and there was no difference in birth weight over time.

Sardjito Hospital, the five district hospitals, and the five health centers in YST contributed with 25\%, 56\% and $19 \%$ of the newborns respectively. First child constituted 26,189 (48.0\%) and later child was 28,410 (52.0\%). The numbers of eligible infants for birth weight, length and head circumference were 54,599, 52,261 and 48,109 respectively (53.3\% boys and $46.7 \%$ girls) (Table 2 ). Mean \pm SD, percentiles 3, 5, 10, 25, 50, 75, 90, 95, 97 of birth weight, length, and head circumferences for boys and girls were presented in Tables 3, 4, 5. Smoothed curves of birth weight, length, and head circumference for boys and girls were presented in Figs. 1, 2, 3, 4, 5, 6 .
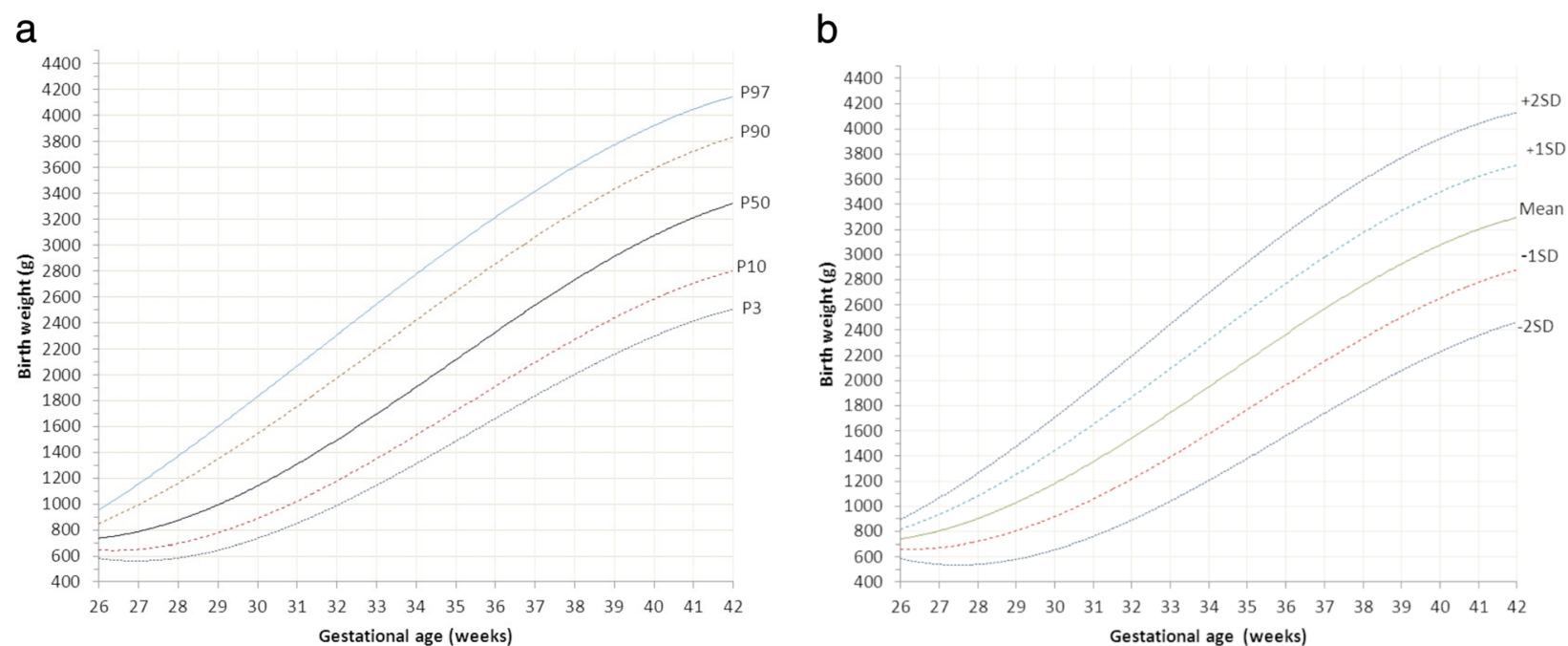

Fig. 2 a Smoothened percentiles for girls' birth weight by gestational age. b. Smoothened mean and standard deviations for girls' birth weight by gestational age 

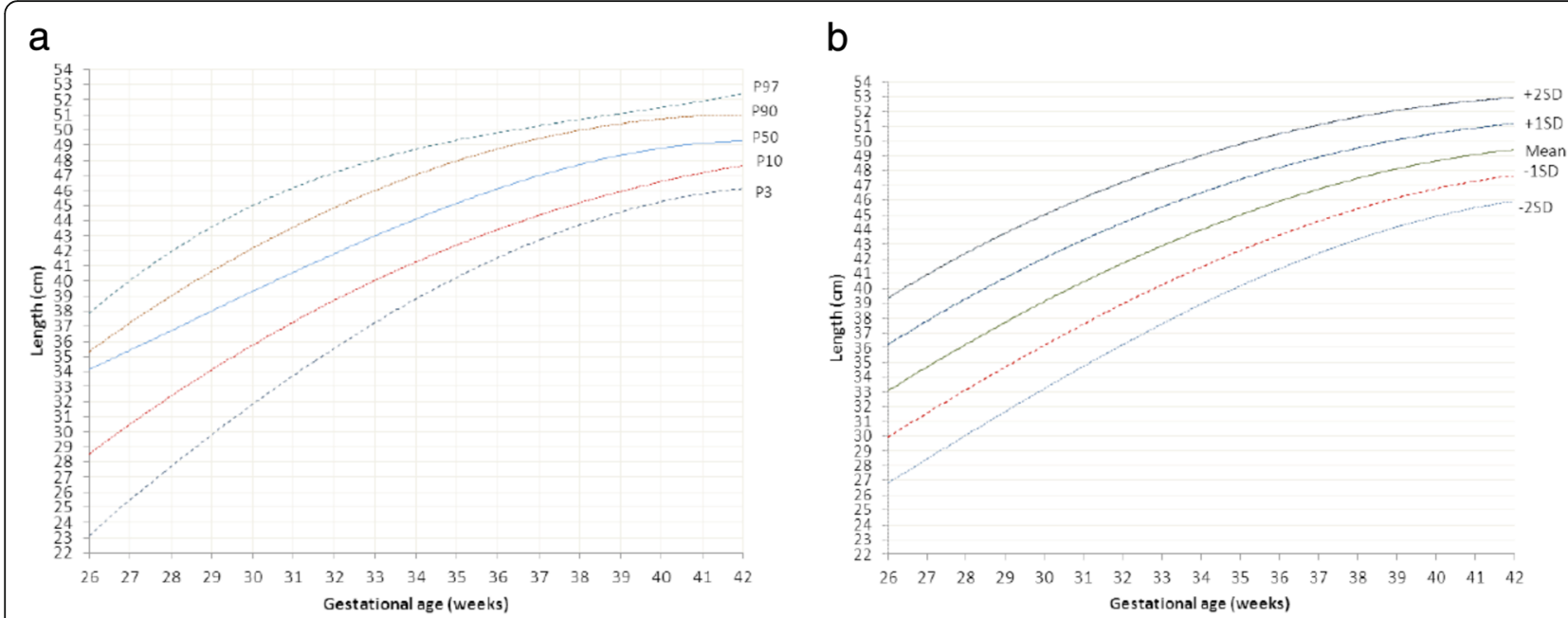

Fig. 3 a Smoothened percentiles for boys' length by gestational age. b. Smoothened mean and standard deviations for boys' length by gestational age

At term (37-42 weeks gestational age) mean birth weight for each gestational age was significantly higher for boys than for girls (Table 6, Fig. 7) and for later born than for first born (Table 7, Fig. 8).

For gestational age $\geq 39$ weeks there was a striking similarity in mean birth weight among Lubchenco's, Alisyahbana's, and our study. The mean birth weight for gestational age $\leq 38$ weeks was lower in our study than that in Lubchenco's. Gestational age 34-37 weeks presented the highest mean birth weight in Alisyahbana's but the lowest in our study (Table 8, Fig. 9).

Tertiles of PI of our study were low $(<2.5)$, average $(2.5-$ $2.8)$ and high $(>2.8)$. The PI of term boys, girls, first and later children in our study were classified into average group. In the preterm, however, it was classified into low group (Tables 6 and 7). The PI for gestational age was consequently lower in our study than in Lubchenco's. The gestational age $\geq 39$ weeks was higher in our study than it was in Lubchenco's and Alisyahbana's (Table 8).

\section{Discussion}

Our study presented girls and boys for birth weight, length and head circumference based on the local data. One of the weaknesses of our study was that it did not have enough low-gestational age infants. Therefore the application of the curve in low gestational age infant must be done carefully.

Moreover, comparison of each gestational age showed higher significance in at term only, but not in preterm. The result was similar to the study by Fok [20] whereby the
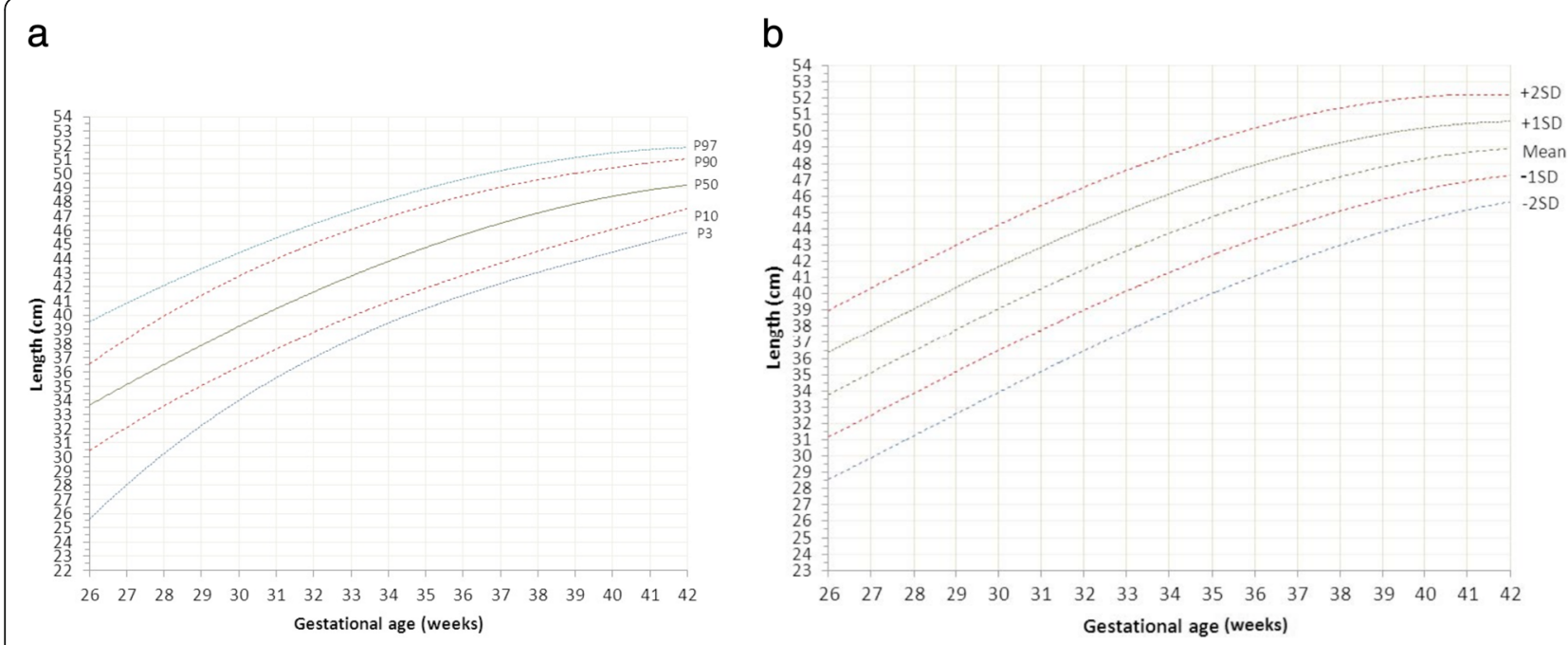

Fig. 4 a Smoothened percentiles for girls' length by gestational age. b. Smoothened mean and standard deviations for girls' length by gestational age 

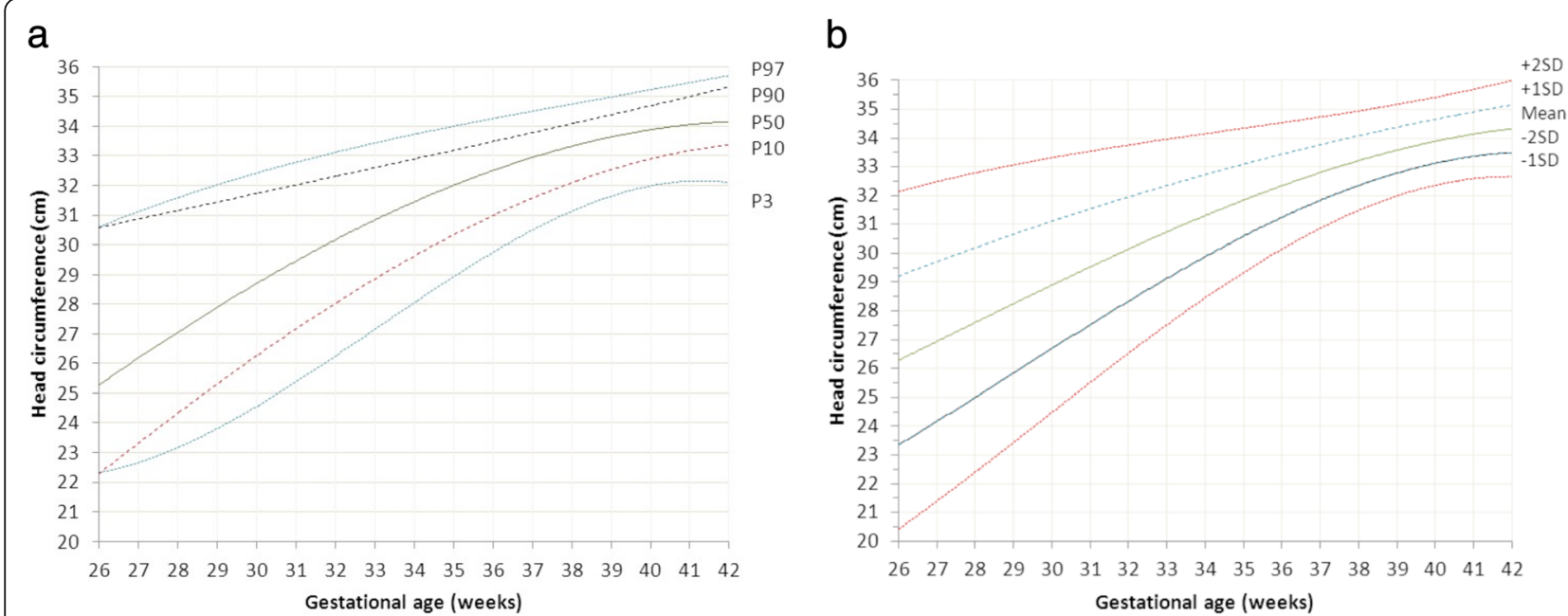

Fig. 5 a Smoothened percentiles for boys' head circumference by gestational age. b. Smoothened mean standard deviations for boys' head circumference by gestational age

mean birth weight of boys consistently exceeded that of girls at 36 weeks or more gestational ages. Lubchenco [1] showed differences of approximately $100 \mathrm{~g}$, significant between boys and girls at 38 to 41 weeks. Skjaerven [16] explained that the effects at 40 weeks in boys were heavier than those in girls. However, Olsen [32] found that all were statistically different by age group, and most were considered clinically different enough. This illustrates the necessity to create separate charts for boys and girls.

Skjaerven [16] pointed out that later children at 40 weeks were between $130-150 \mathrm{~g}$ heavier than first children. This was similar to our study which showed that each gestational age, at term later-born children were significantly $100-130 \mathrm{~g}$ heavier $(p<0.001)$ than first-born children. In preterm there was no significant difference, though. Nevertheless, Alisyahbana reported that for every gestational age and percentile, later-born children were heavier than first born-children [27].

We could not compare the mean birth weight for each gestational age in our study and that in the previous studies by Lubchencho and Alisyahbana, since there was no information on standard deviation. Thus, the comparison was based on mean birth weight for sexes combine because no information of separated boys and girls was found in Alisyahbana's. Similarly, comparison of our study and Lubchenco's showed that for gestational age $\leq 38$ weeks the mean birth weight was lower in our study. This was probably due to the relatively high number of infants with small for gestational age in our population for term and preterm, which needed further investigation.

Compared with Alisyahbana's study, for gestational age 34-37 weeks the mean birth weight was lower in a

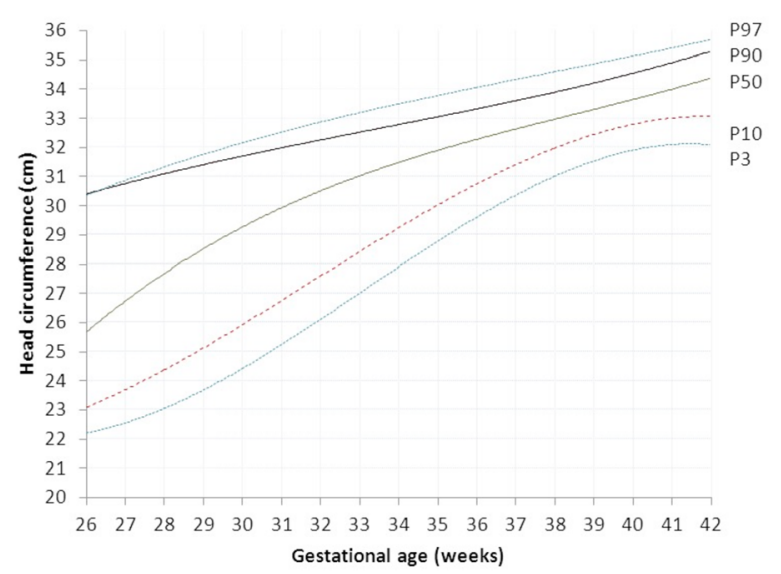

b

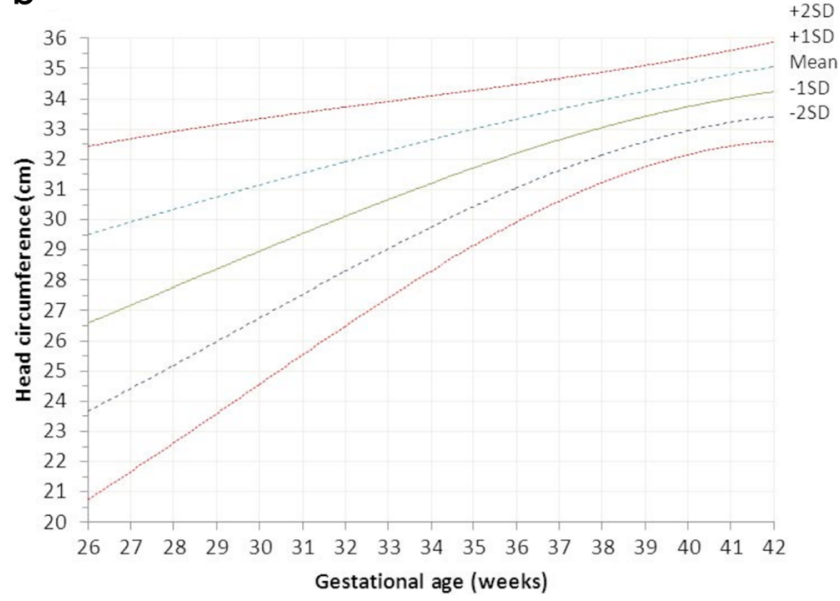

Fig. 6 a Smoothened percentiles for girls' head circumference by gestational age. b. Smoothened mean standard deviations for girls' head circumference by gestational age 
Table 6 Mean birth weight, standard deviation, ponderal index, classification for boys and girls by gestational age

\begin{tabular}{|c|c|c|c|c|c|c|c|c|c|c|c|}
\hline \multirow{2}{*}{$\begin{array}{l}\text { GA } \\
(w)\end{array}$} & \multicolumn{3}{|l|}{ Boys } & \multicolumn{3}{|l|}{ Girls } & \multirow[t]{2}{*}{$p$} & \multicolumn{2}{|c|}{ Boys } & \multicolumn{2}{|c|}{ Girls } \\
\hline & No of cases & Mean (g) & SD & No of cases & Mean (g) & SD & & $\mathrm{PI}$ & $C$ & $\mathrm{Pl}$ & C \\
\hline 26 & 55 & 768.1 & 170.2 & 48 & 680.8 & 134.8 & 0.005 & 2.1 & $L$ & 1.7 & L \\
\hline 27 & 39 & 866.6 & 152.8 & 41 & 844.3 & 156.2 & 0.52 & 2.4 & $L$ & 2.0 & L \\
\hline 28 & 50 & 968.7 & 152.9 & 59 & 945.3 & 119.2 & 0.37 & 2.2 & $L$ & 2.1 & L \\
\hline 29 & 52 & 1057 & 157.0 & 42 & 1023 & 109.6 & 0.25 & 2.0 & $L$ & 1.9 & L \\
\hline 30 & 70 & 1246 & 202.3 & 49 & 1151 & 230.2 & 0.019 & 2.1 & $L$ & 2.0 & L \\
\hline 31 & 89 & 1409 & 282.3 & 74 & 1374 & 294.1 & 0.45 & 2.0 & $L$ & 1.9 & L \\
\hline 32 & 223 & 1705 & 377.5 & 171 & 1711 & 441.3 & 0.87 & 2.2 & $L$ & 2.2 & L \\
\hline 33 & 258 & 1750 & 442.7 & 211 & 1692 & 406.2 & 0.15 & 2.3 & $L$ & 2.3 & L \\
\hline 34 & 473 & 1917 & 407.1 & 392 & 1862 & 386.5 & 0.043 & 2.4 & $L$ & 2.4 & $L$ \\
\hline 35 & 541 & 2035 & 378.5 & 515 & 2046 & 386.3 & 0.64 & 2.4 & $L$ & 2.4 & $L$ \\
\hline 36 & 868 & 2382 & 430.7 & 812 & 2335 & 436.8 & 0.026 & 2.4 & $L$ & 2.4 & L \\
\hline 37 & 1576 & 2643 & 427.1 & 1384 & 2589 & 397.0 & $<0.001$ & 2.5 & A & 2.5 & A \\
\hline 38 & 3799 & 2862 & 404.8 & 3318 & 2800 & 375.1 & $<0.001$ & 2.6 & $A$ & 2.6 & A \\
\hline 39 & 6915 & 3069 & 382.3 & 6065 & 2997 & 371.4 & $<0.001$ & 2.7 & A & 2.7 & A \\
\hline 40 & 8755 & 3184 & 410.5 & 7607 & 3099 & 393.6 & $<0.001$ & 2.8 & $A$ & 2.7 & A \\
\hline 41 & 3812 & 3358 & 445.0 & 3254 & 3259 & 447.4 & $<0.001$ & 2.8 & A & 2.8 & A \\
\hline 42 & 1537 & 3295 & 463.5 & 1445 & 3208 & 447.3 & $<0.001$ & 2.8 & A & 2.8 & A \\
\hline
\end{tabular}

C Classification; L Low, A Average, $H$ High; GA Gestational Age; SD Standard Deviation; P Percentiles; $g$ gram; $w$ week

our study; which was probably due to the differences of sample. Our study had more data from health centers, district hospitals, and 1 teaching hospital, whereas Alisyahbana's study collected the data from 14 teaching hospitals with middle and high socio-economic status. In addition, the numbers of samples in our study were much higher with updated reference for 26 to 42 weeks gestational age, meanwhile Alisyahbana's was only 3442 weeks. Unfortunately, we could not compare our result with Niklasson's curve [20], since we were not able to find the data in the Niklasson's articles.

Tertiles of PI for our study were similar to those of Morris's [31] report, which showed $<2.6$ low, 2.6-2.8 average and $>2.8$ high. The PI of at term of boys, girls,

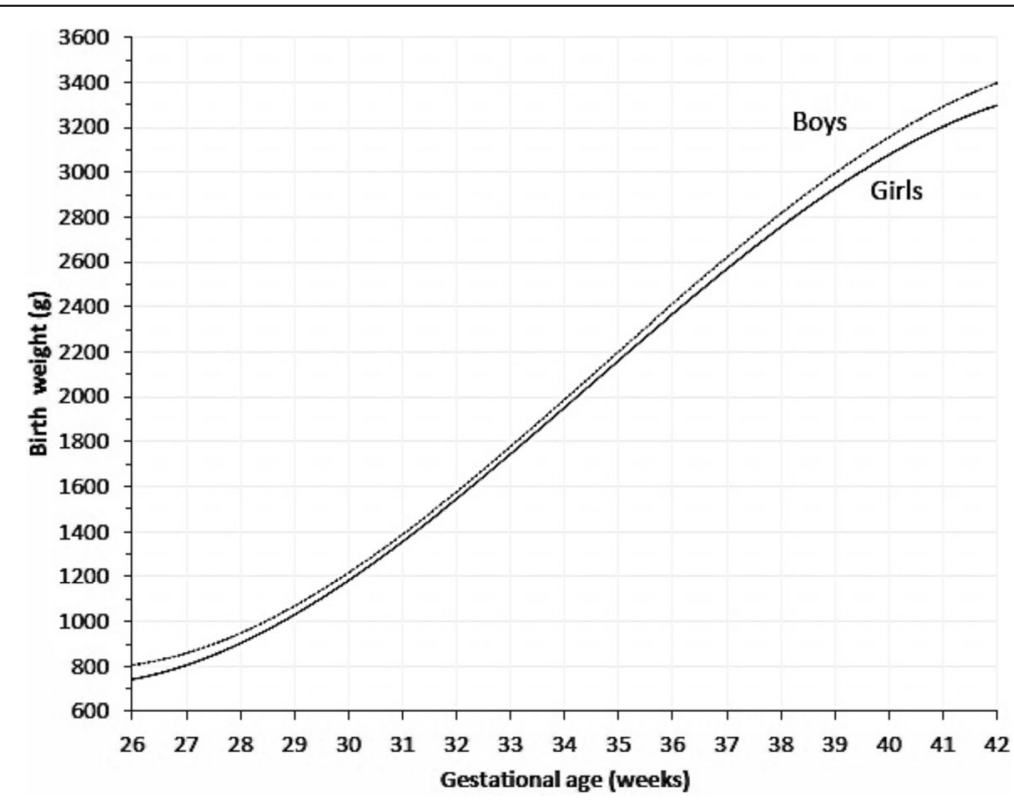

Fig. 7 Mean birth weight for boys' and girls' by gestational age 
Table 7 Mean birth weight, standard deviation, Ponderal index and classification by birth order and gestational age

\begin{tabular}{|c|c|c|c|c|c|c|c|c|c|c|c|}
\hline \multirow{2}{*}{$\begin{array}{l}\text { GA } \\
(w)\end{array}$} & \multicolumn{3}{|l|}{ First child } & \multicolumn{3}{|l|}{ Later children } & \multirow[t]{2}{*}{$p$} & \multicolumn{2}{|c|}{ First child } & \multicolumn{2}{|c|}{ Later children } \\
\hline & No of cases & Mean $(\mathrm{g})$ & SD & No of cases & Mean (g) & SD & & $\mathrm{PI}$ & $C$ & $\mathrm{Pl}$ & C \\
\hline 26 & 48 & 723.6 & 173.7 & 55 & 730.7 & 148.8 & 0.83 & 2.0 & $L$ & 1.9 & $L$ \\
\hline 27 & 40 & 832.8 & 145.3 & 40 & 877.5 & 160.8 & 0.18 & 2.2 & $\mathrm{~L}$ & 2.3 & $\mathrm{~L}$ \\
\hline 28 & 60 & 951.6 & 139.1 & 49 & 961.3 & 132.2 & 0.71 & 2.1 & $\mathrm{~L}$ & 2.1 & L \\
\hline 29 & 56 & 1041 & 107.7 & 38 & 1043 & 175.3 & 0.94 & 2.0 & $\mathrm{~L}$ & 2.0 & $L$ \\
\hline 30 & 57 & 1199 & 203.6 & 62 & 1214 & 232.6 & 0.70 & 2.1 & $\mathrm{~L}$ & 2.0 & L \\
\hline 31 & 84 & 1413 & 315.6 & 79 & 1372 & 254.2 & 0.37 & 2.0 & $\mathrm{~L}$ & 2.0 & $L$ \\
\hline 32 & 214 & 1698 & 393.4 & 180 & 1720 & 421.0 & 0.58 & 2.2 & $\mathrm{~L}$ & 2.2 & L \\
\hline 33 & 228 & 1689 & 407.1 & 241 & 1757 & 443.7 & 0.083 & 2.3 & $\mathrm{~L}$ & 2.3 & $\mathrm{~L}$ \\
\hline 34 & 508 & 1874 & 386.2 & 357 & 1917 & 414.8 & 0.12 & 2.3 & $\mathrm{~L}$ & 2.4 & $L$ \\
\hline 35 & 628 & 2034 & 361.9 & 428 & 2049 & 410.4 & 0.54 & 2.4 & $\mathrm{~L}$ & 2.4 & $\mathrm{~L}$ \\
\hline 36 & 906 & 2328 & 390.9 & 774 & 2396 & 477.6 & 0.002 & 2.4 & $\mathrm{~L}$ & 2.5 & A \\
\hline 37 & 1525 & 2569 & 381.3 & 1435 & 2669 & 440.7 & $<0.001$ & 2.5 & A & 2.6 & A \\
\hline 38 & 3510 & 2783 & 361.3 & 3607 & 2883 & 414.7 & $<0.001$ & 2.6 & A & 2.7 & A \\
\hline 39 & 6159 & 2983 & 359.5 & 6821 & 3083 & 389.7 & $<0.001$ & 2.7 & A & 2.7 & A \\
\hline 40 & 7527 & 3075 & 377.2 & 8835 & 3204 & 418.0 & $<0.001$ & 2.7 & A & 2.8 & A \\
\hline 41 & 3289 & 3246 & 443.1 & 3777 & 3370 & 445.8 & $<0.001$ & 2.8 & $A$ & 2.9 & $\mathrm{H}$ \\
\hline 42 & 1350 & 3199 & 440.7 & 1632 & 3297 & 466.9 & $<0.001$ & 2.7 & $A$ & 2.8 & A \\
\hline
\end{tabular}

C Classification; L Low; A Average; $H$ High; GA Gestational Age; SD Standard Deviation; P Percentiles; $g$ gram; w week

first, and later children in our study was at average. However, in the preterm it was low.

Lubchenco [26] reported that there was an increasing weight-length ratio (PI) as gestation progressed; the babies became heavier for length as they approached near full term. Similar to our study, PI was classified into preterm and average in near term (35-36 weeks) and term (>37 weeks).

Thus, the combination of short and low PI at birth may well provide a useful classification of the anthropometric

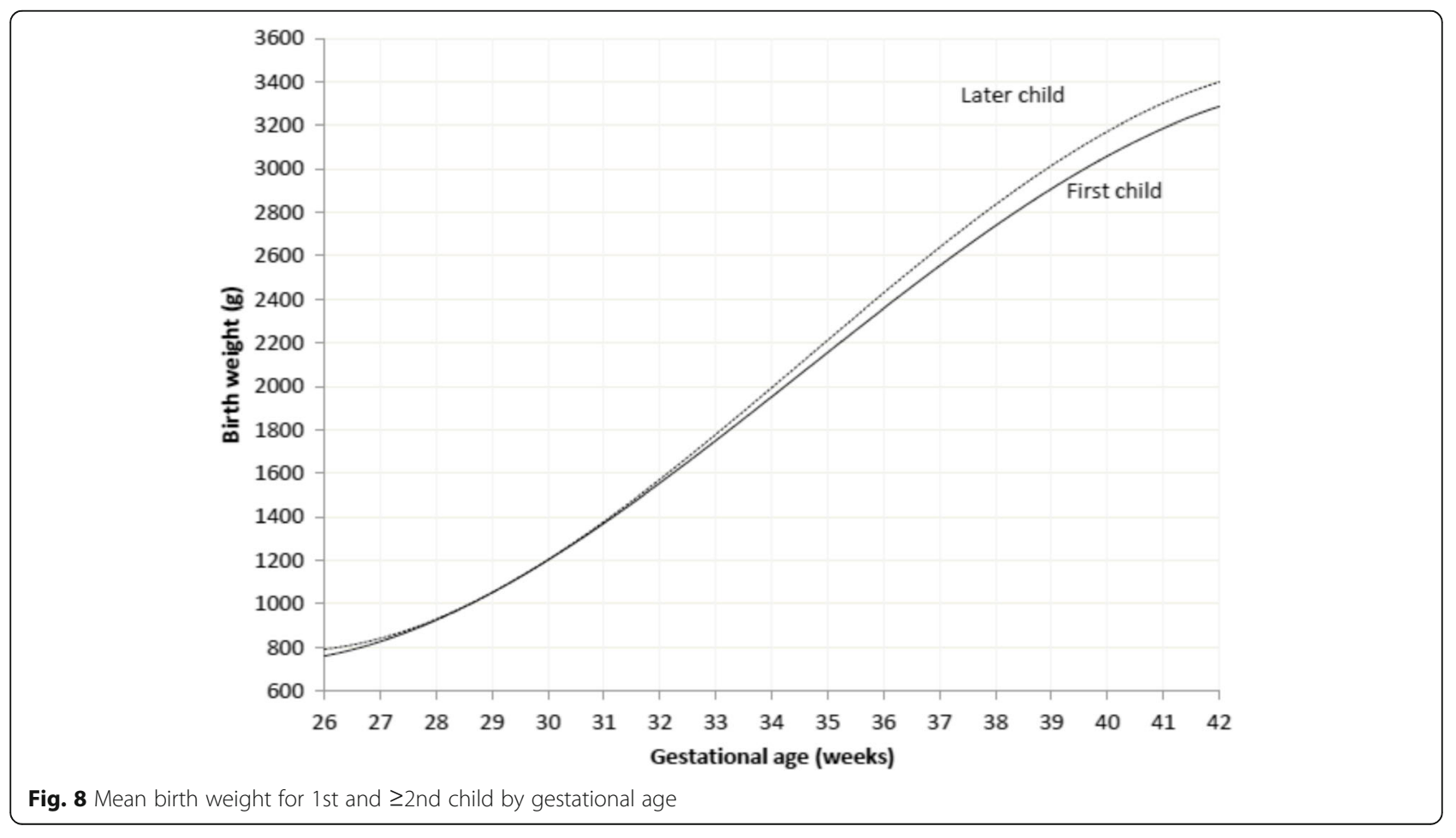


Table 8 Mean birth weight, Ponderal index, classification in Lubchenco's, Alisyahbana's and present study by gestational age

\begin{tabular}{|c|c|c|c|c|c|c|c|c|c|c|c|c|}
\hline \multirow[t]{2}{*}{ GA (w) } & \multicolumn{4}{|l|}{ Lubchenco } & \multicolumn{4}{|l|}{ Alisyahbana } & \multicolumn{4}{|c|}{ Present study } \\
\hline & No of cases & BW (g) & $\mathrm{PI}$ & C & No of cases & BW (g) & $\mathrm{PI}$ & $\bar{C}$ & No of cases & BW $(g)$ & $\mathrm{PI}$ & C \\
\hline 26 & 68 & 1001 & 2.2 & $\mathrm{~L}$ & & & & & 103 & 727 & 1.9 & $\bar{L}$ \\
\hline 27 & 72 & 1065 & 2.2 & $L$ & & & & & 80 & 855 & 2.1 & L \\
\hline 28 & 118 & 1236 & 2.2 & $L$ & & & & & 109 & 956 & 2.1 & L \\
\hline 29 & 143 & 1300 & 2.3 & $L$ & & & & & 94 & 1042 & 2.0 & L \\
\hline 30 & 109 & 1484 & 2.3 & $L$ & & & & & 119 & 1207 & 2.0 & L \\
\hline 31 & 147 & 1590 & 2.4 & $\mathrm{~L}$ & & & & & 163 & 1393 & 1.9 & L \\
\hline 32 & 124 & 1732 & 2.4 & $L$ & & & & & 394 & 1708 & 2.2 & L \\
\hline 33 & 118 & 1957 & 2.4 & $\mathrm{~L}$ & & & & & 469 & 1724 & 2.3 & $L$ \\
\hline 34 & 145 & 2278 & 2.5 & A & 43 & 2553 & 2.5 & A & 865 & 1892 & 2.3 & L \\
\hline 35 & 188 & 2483 & 2.5 & A & 70 & 2704 & 2.6 & A & 1056 & 2040 & 2.4 & $L$ \\
\hline 36 & 202 & 2753 & 2.5 & A & 136 & 2849 & 2.4 & $L$ & 1680 & 2359 & 2.5 & A \\
\hline 37 & 372 & 2800 & 2.6 & A & 262 & 2819 & 2.5 & A & 2960 & 2618 & 2.5 & A \\
\hline 38 & 636 & 3025 & 2.6 & $A$ & 565 & 2903 & 2.5 & A & 7117 & 2833 & 2.6 & A \\
\hline 39 & 1010 & 3130 & 2.6 & A & 1309 & 3066 & 2.6 & A & 12980 & 3035 & 2.7 & A \\
\hline 40 & 1164 & 3226 & 2.6 & $A$ & 1710 & 3146 & 2.5 & A & 16362 & 3145 & 2.7 & A \\
\hline 41 & 632 & 3307 & 2.6 & $A$ & 962 & 3205 & 2.6 & A & 7066 & 3312 & 2.8 & A \\
\hline 42 & 336 & 3308 & 2.6 & $A$ & 446 & 3228 & 2.6 & A & 2982 & 3253 & 2.7 & A \\
\hline Total & 5584 & & & & 5503 & & & & 54599 & & & \\
\hline
\end{tabular}

C Classification; L Low; A Average; $H$ High; GA Gestational Age; PI Ponderal Index; BW Birth Weight; g gram; w week

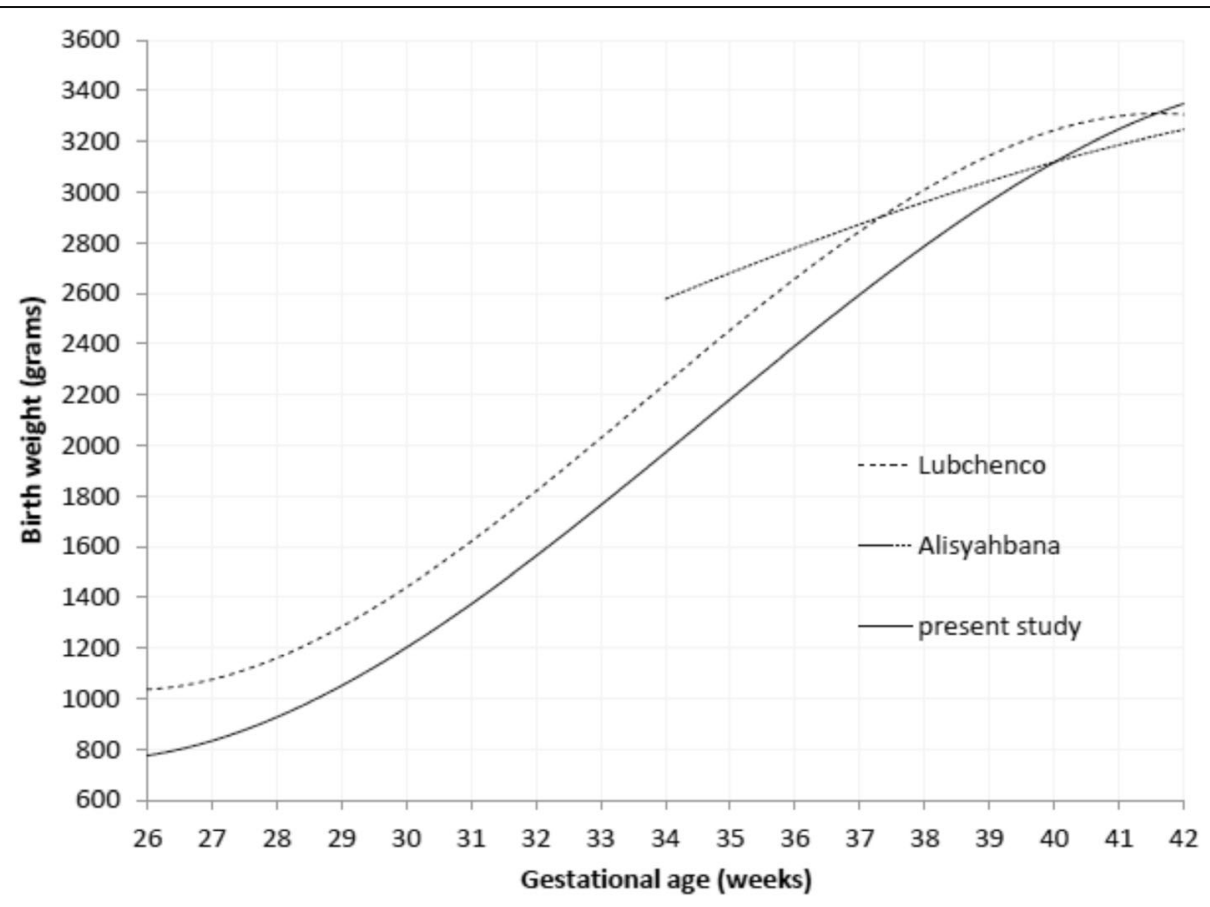

Fig. 9 Mean birth weight by gestational age according to Lubchenco's, Alisyahbana's and present study 
status of the newborns. Infants who were born short with low PI were at risk of mortality and severe morbidity during infancy [31]. The low PI of Lubchenco's was for gestational age $\leq 33$ weeks, whereas it was for $\leq 35$ weeks in our study. If we found a short newborns $<35$ weeks of gestational age, therefore, he/she would be at high risk for morbidity and mortality.

Important cut off points for risk assessment of the $3^{\text {rd }}$ and $97^{\text {th }}$ percentiles, -2 SD or +2 SD were added. We expect that these curves would be useful for the care of Indonesian newborns.

\section{Conclusions}

Our study separated girls and boys for birth weight, length and head circumference based on the local data. At term, mean birth weight of boys was significantly higher than that of girls, mean birth weight of firstborn children was significantly lower than that of later born-children; but in preterm, both did not suggest significant difference.

For gestational age $\geq 39$ weeks there was mean birth weight similarity to Lubchenco's, Alisyahbana's, and our study. When compared with Lubchenco's study, the mean birth weight for gestational age $\leq 38$ weeks was lower in our study. However, for 34-37 weeks, the mean birth weight in our study was lower than that in Alisyahbana's study.

The PI of term for boys and girls and first and laterborn children was classified into average, whereas that of preterm was classified into low. The PI for gestational age $\leq 35$ weeks was lower in our study than in Lubchenco's; however, for gestational age $\geq 39$ weeks it was higher in our study than in Lubchenco's and Alisyahbana's.

Updated and improved neonatal reference curves for birth weight, supine length, and head circumference are important to classify high risk newborns in specific area and to recognize those requiring attention with regard to recent condition.

\section{Abbreviations \\ A: Average; C: Classification; GA: Gestational age; H: High; HC: Head circumference; L: Low; LMP: Last menstrual period; MP: Maternal-perinatal; PI: Ponderal index; SD: Standard deviation; SGA: Small for gestational age; USG: Ultrasonography; YST: Yogyakarta special territory}

\footnotetext{
Acknowledgements

We would like to thank the late Professor Ahmad Surjono and all the members of MP Audit team of Perinatal Epidemiology team at the Medical Faculty of Gadjah Mada University and all the members of MP Audit team in YST, Yogyakarta Municipality, Districts of Bantul, Kulonprogo, Gunung Kidul, and Sleman. We also thank the physicians, pediatricians, obstetricians, midwives, nurses, and health workers in Sardjito Hospital, the five district hospitals and the five health centers in Tegalrejo, Imogiri, Temon, Ponjong, and Ngemplak. Our gratitude is also addressed to Hans Stenlund, Anneli Ivarsson, Setya Wandita, Tunjung Wibowo, Althaf, Diah, Hilwi, Wulan, Retno, Juwariyem, Kusmiyati, Widodo, Ananta, Shianita, Friska, Toni and Agus Herwindo.
}

\section{Funding}

Not applicable.

\section{Availabillity of data and materials}

The data and materials are stored at the Department of Child Health, Neonatology Division, Faculty of Medicine, Universitas Gadjah Mada, Yogyakarta.

\section{Authors' contributions}

All authors participated in the study design and interpretation of data. ELH conceptualized and designed the study, coordinated and supervised data collection, acquisition of data, analysis and interpretation of data, as well as drafted the article. HNL conceptualized and designed the study, analyzed and interpreted the data, and conducted a critical review. Md H designed the data collection instruments, coordinated and supervised the data collection, acquired the data, and drafted the article. EPP carried out the initial analysis of the study. LN conceptualized and designed the study, carried out analysis and interpretation of the data, and drafted the initial article. All authors read and approved the final manuscript.

\section{Competing interests}

The authors have indicated they have no financial relationships relevant to this article to disclose. This manuscript does not have conflict of interest with any individual or institution.

\section{Consent for publication}

We shall not display the data/photos/videos of the subject of the study.

\section{Ethics approval and consent to participate}

This study has been approved by Medical and Health Research Ethics Committee Faculty of Medicine Universitas Gadjah Mada-Dr. Sardjito General Hospital.

\section{Author details}

'Department of Child Health, Faculty of Medicine, Gadjah Mada University, Sardjito General Hospital, Jl. Kesehatan No. 1, Yogyakarta 55284, Indonesia. 2Department of Pediatrics, Vrije Universiteit Medical Center, P.O. Box 7057, 1007 MB Amsterdam, The Netherlands. ${ }^{3}$ Faculty of Medicine, Gadjah Mada University/Sardjito General Hospital, Jl. Kesehatan No. 1, Yogyakarta 55284, Indonesia. ${ }^{4}$ Public Health and Clinical Medicine, Umeå University, SE-901 87 Umeå, Sweden.

Received: 23 March 2016 Accepted: 8 November 2016

Published online: 21 November 2016

\section{References}

1. Lubchenco LO, Hansman C, Dressler M, Boyd E. Intrauterine growth as estimated from live born birth-weight data at 24 to 42 weeks of gestation. Pediatrics. 1963;32(5):793-800.

2. Usher R, McLean F. Intrauterine growth of live-born Caucasian infants at sea level: Standards obtained from measurement in 7 dimensions of infants born between 25 and 44 weeks of gestation. J Pediatr. 1969;74(6):901-10.

3. Battaglia FC, Lubchenco LO. A practical classification of newborns infants by weight and gestational age. J Pediatr. 1967;71(2):159-63.

4. Alexander GR, Kogan MD, Himes JH, Mor JM, Goldberg R. Racial differences in birth weight for gestational age and infant mortality in extremely-low-risk US populations. Paediatr Perinat Epidemiol. 1999;13(2):205-17.

5. Thureen PJ, Anderson MS, Hay WH. The small for gestational age infant. NeoReviews. 2001;2(6):e139-49.

6. Lee PA, Chernausek SD, Hokken-Koelega ACS, Czernichow P. for the International Small for Gestational Age Advisory Board. International small for gestational age advisory board consensus development conference statement: Management of short children born small for gestational age, April 24-October 1, 2001. Pediatrics. 2003;111(6 Pt 1):1253-61.

7. Ferdynus C, Quantin C, Abrahamowicz M, et al. Can birth weight standards based on healthy populations improve the identification of small-forgestational-age newborns at risk of adverse neonatal outcomes. Pediatrics. 2009;123(2):723-30.

8. Alexander GR, Himes JH, Kaufman RB, Mor J, Kogan M. A United States national reference for fetal growth. Obstet Gynecol. 1996;87(2):163-8.

9. Dunn PM. A perinatal growth chart for international reference. Acta Paediatr Scand Suppl. 1985;319:180-7.

10. Munjanja SP, Masona D. Zimbabwean birth weight for gestational standards. Cent Afr J Med. 1990;36(6):144-7. 
11. Arbuckle TE, Wilkins R, Sherman GJ. Birth weight percentiles by gestational age in Canada. Obstet Gynecol. 1993;81(1):39-48.

12. Ulrich M, Høst A, Kamper J, Kroun M, Pedersen VF, Søgaard J. Weight, length, and head circumference standards based on Danish newborns boys and girls in gestational weeks 25 to 43. Dan Med Bull. 1997;44(4):436-9.

13. Bakketeig LS. Current growth standards, definitions, diagnosis and classification of fetal growth retardation. Eur J Clin Nutr. 1998;52 Suppl 1:S1-4.

14. Skjaerven R, Gjessing HK, Bakketeig LS. Birth weight by gestational age in Norway. Acta Obstet Gynecol Scand. 2000;79(6):440-9.

15. Ovali F. Intrauterine growth curves for Turkish infants born between 25 and 42 weeks of gestation. J Trop Pediatr. 2003:49(6):381-3.

16. Kierans WJ, Joseph KS, Luo ZC, Platt R, Wilkins R, Kramer MS. Does one size fit all? The case for ethnic-specific standards of fetal growth. BMJ Pregnancy Childbirth. 2008;8:1.

17. Goldenberg RL, Cutter GR, Hoffman HJ, Foster JM, Nelson KG, Hauth JC. Intrauterine growth retardation: Standards for diagnosis. Am J Obstet Gynecol. 1989;161(2):271-7.

18. Kramer SM, Platt RW, Wen SW, et al. A new and improved population-based Canadian reference for birth weight for gestational age. Pediatrics. 2001; 108(2):E35.

19. Niklasson A, Ericson A, Fryer JG, Karlberg J, Lawrence C, Karlberg P. An update of the Swedish reference standards for weight, length and head circumference at birth for given gestational age (1977-1981). Acta Paediatr Scand. 1991;80(8-9):756-62.

20. Fok TF, So H, Wong E, et al. Updated gestational age specific birth weight, crown-heel length, and head circumference of Chinese newborns. Arch Dis Child Fetal Neonatal Ed. 2003;883:F229-36.

21. Visser GH, Eylers PH, Elferink-Stinkens PM, Merkus HM, Wit JM. New Dutch reference curves for birthweight by gestational age. Early Hum Dev. 2009; 85(12):737-44.

22. Dobbins $T A$, Sullivan EA, Roberts $C L$, Simpson JM. Australian national birth weight percentiles by sex and gestational age, 1998-2007. MJA. 2012;197: 291-4.

23. Li Z, Umstad MP, Hilder L, Xu F, Sullivan EA. Australian national birthweight percentiles by sex and gestational age for twins, 2001-2010. BMC Pediatr. 2015;15:148

24. Mathai M, Jacob S, Karthikeyan NG. Birthweight standards for South Indian babies. Indian Pediatr. 1996;33(3):203-9.

25. Lubchenco LO, Hansman C, Boyd E. Intrauterine growth in length and head circumference as estimated from live births at gestational ages from 26 to 42 weeks. Pediatrics. 1966;37(3):403-8.

26. Alisyahbana A, Chaerulfatah A, Usman A, Sutresnawati S. Anthropometry of newborns infants born in 14 teaching centers in Indonesia. Paediatr Indones. 1994;34:62-123.

27. Yogyakarta Health Office. Health profile in Yogyakarta Special Territory. 2003. (in Indonesian)

28. $\mathrm{MOH}$ Republic of Indonesia. Technical guidance of Maternal-Perinatal Audit at district or municipal. 3rd ed. Jakarta, Indonesia; 2007 (in Indonesian)

29. Supratikto G, Wirth ME, Achadi E, Cohen S, Ronsmans C. A district-based audit of the causes and circumstances of maternal deaths in South Kalimantan, Indonesia. Bull WHO. 2002;80(3):228-34.

30. Dubowitz LM, Dubowitz V, Goldberg C. Clinical assessment of gestational age in the newborns infant. J Pediatr. 1970;77(1):1-10.

31. Morris SS, Victora CG, Barros FC, et al. Length and Ponderal index at birth: associations with mortality, hospitalizations, development and post-natal growth in Brazilian infants. Int J Epidemiol. 1998;27(2):242-7.

32. Olsen IE, Groveman SA, Lawson ML, Clark RH, Zemel BS. New intrauterine growth curves based on United States data. Pediatrics. 2010;125(2):e214-224.

\section{Submit your next manuscript to BioMed Central and we will help you at every step:}

- We accept pre-submission inquiries

- Our selector tool helps you to find the most relevant journal

- We provide round the clock customer support

- Convenient online submission

- Thorough peer review

- Inclusion in PubMed and all major indexing services

- Maximum visibility for your research

Submit your manuscript at www.biomedcentral.com/submit

C) Biomed Central 